\title{
Functional brain imaging and its application to uncover mechanisms driving food intake in humans
}

\author{
Claudio L. Lafortuna, Sarah A. Tabozzi, Rizzo Giovanna \\ Institute of Molecular Bioimaging and Physiology, Consiglio Nazionale delle Ricerche, Segrate (Milano), Italy
}

Correspondence: Claudio L. Lafortuna. Address: Institute of Molecular Bioimaging and Physiology (IBFM), CNR, Via F.Ili Cervi 93, 20090, Segrate (MI), Italy. E-mail: claudio.lafortuna@cnr.it

Received: November 13, 2013

Accepted: May 7, 2014

Online Published: July 2, 2014

DOI : $10.5430 /$ jbgc.v4n3p10

URL: http://dx.doi.org/10.5430/jbgc.v4n3p10

\section{Abstract}

The control of food intake involves complex and powerful neural mechanisms whose functioning has critical repercussions for alimentary behaviours and the regulation of energy balance. Recent research also from cognitive neurosciences indicates that homeostatic (repletion-driven) and hedonic (reward-driven) systems in the brain concur in achieving an integrated regulation of human alimentary activity.

Modern societal changes, related to unrestricted availability of energy-dense palatable foods at low costs and widespread presence of compelling alimentary cues, are considered to contribute to a food consumption driven mainly by hedonic properties rather than energy requirements, and result among the causes of worldwide obesity epidemics.

Functional neuroimaging permits the exploration of the human brain systems involved under the different conditions of alimentary relevance, through the quantitative evaluation of regional blood flow, metabolic activation of defined cerebral networks or molecular bioavailability of brain receptors specifically traced. Such a framework of different imaging techniques appears uniquely suited to investigate the functional integration of the neural processes which underpin the interplay between homeostatic drive for feeding and the conscious experience of pleasure and reward concurring to the control of food intake. Therefore, these techniques provide an invaluable tool in gaining a detailed comprehension of physiology underlying alimentary behaviours and their derangements, and in detecting new strategies against obesity which interact also on brain mechanisms involved in the control of food intake and energy balance.

In the present short review, basic principles of the most used functional neuroimaging techniques will be examined and the commonest acquisition protocols and processing methods will be briefly presented, along with a short overview of the brain systems involved in food intake regulation and a concise report of the main findings obtained with these techniques.

\section{Key words}

Food intake, Homeostatic hunger, Hedonic hunger, Brain imaging, Obesity

\section{Introduction}

Food intake relies upon a complex interplay of physiological, environmental, and cognitive regulatory factors. These regulating mechanisms are particularly elaborate for mammals which have to cope with the need to keep a relatively constant body temperature in front to a wide variety of ambient perturbations. In conditions where survival is secured through the maintenance of energy homeostasis and the avoidance of starvation, physiological hunger signals generally 
have preponderance over cognitive factors, being referred to as homeostatic hunger ${ }^{[1-3]}$. However, in modern environments with abundant, constant and inexpensive availability of highly palatable and calorically dense foods, evidence suggests that most eating occurs prior to the development of significant energy deprivation or at least for reasons other than acute energy depletion ${ }^{[4]}$. The resulting motivation for food intake is thus considered principally driven by the reward value of foods which overrides internal signals of satiety and gives rise to the development of a separate motivation to consume palatable foods mainly for their hedonic appeal, under the urge of the so-called hedonic hunger ${ }^{[1-3]}$. Rapid societal changes in relation to food availability and consumption, driven mainly by gustatory properties rather than energy content, are being increasingly recognised as strongly contributing to the recent surge of obesity and its associated co morbidities worldwide ${ }^{[5,6]}$.

The initiation and maintenance of ingestive behaviour is thus determined by the balance of metabolic (homeostatic) and non-metabolic (hedonic) factors which regulate appetite and food intake ${ }^{[7-9]}$. Complex (and not completely known) brain mechanisms in the hypothalamic nuclei modulate the drive for feeding by receiving short-term gastrointestinal information (gut hormones) related to nutritional stimuli ${ }^{[10,11]}$ and long-term adiposity signals (leptin) related to energy stores and body weight regulation ${ }^{[12]}$, and by integration of powerful inputs from higher cortical centres and nervous structures concerned with pleasure and reward ${ }^{[9]}$.

Thus, eating results to be not a simple stereotyped task, but a complex set of processes carried out with the involvement of peripheral and central nervous system (CNS) to coordinate activities ranging from the obtainment of sensory information about food to the evaluation of desirability and selection of appropriate behaviour under the internal drive of appetite.

Under this perspective, understanding of the neurophysiology of the alimentary behaviour requires a technical approach able to take into account the global participation of the brain in this process. Functional neuroimaging, a term incorporating a number of non-invasive brain imaging techniques for the assessment of neural activation correlated with cognitive and behavioural processes, has recently provided a powerful tool for exploration of brain systems involved in networks mediating appetite and food intake ${ }^{[13-15]}$.

A number of neuroimaging methods are currently available for the in vivo examination of the brain under normal and pathological conditions. Among these, magnetic resonance imaging (MRI) and x-ray computed tomography (CT) provide information about brain structure; other techniques such as positron emission tomography (PET), single photon emission tomography (SPECT) and functional MRI (fMRI) allow the investigation of the functional activity of the human brain, by measurement of blood flow, metabolism and receptor distribution ${ }^{[16,17]}$. Each of these techniques presents relative advantages and limitations in the ability to resolve temporally and spatially cerebral processes.

In recent years, the increased availability of neuroimaging techniques for the evaluation of brain responses to a variety of alimentary stimuli and food cues has led to a considerable rise of studies in normal weight and obese individuals, under fed and fasted, to better identify the brain mechanisms involved in the regulation of food intake of potential importance for the development of behavioural strategies and pharmacological therapies in the fight against obesity.

Initially, in this article the basic principles of the most used functional neuroimaging methods, fMRI and PET, will be reviewed and the commonest acquisition protocols and processing methods will be briefly presented. A short overview of the brain systems involved in food intake regulation will then follow along with a concise report of the main findings obtained with neuroimaging techniques.

\section{I maging techniques}

\section{1 fMRI}

fMRI investigates neural activation in the cerebral areas functionally involved, by measuring the regional haemodynamic response. Functional activity in a cerebral area causes an increase in local blood flow, leading to a local increase of 
oxygenated blood. Due to the diamagnetic behaviour of oxygenated blood (with respect to the paramagnetic deoxygenated blood), the cerebral areas involved in activation present a decrease in the local susceptibility effect, and thus an increase in the signal intensity, as observed in a T2-weighted or T2*-weighted MRI imaging (the so-called Blood Oxygenation Level Dependent, BOLD, effect) ${ }^{[18,19]}$. In the last decades, fMRI has opened an invaluable window into brain activity, with a time resolution that was previously inconceivable using methods based on radioactive tracers, but with an anatomical specificity in depth never attained with non-invasive EEG analysis.

\subsection{1 fMRI acquisition: technical aspects}

In MRI, signal intensity depends on the intensity of the magnetic field. Many fMRI studies have been performed at 1.5 Tesla by commercial scanners. In the last years 3 Tesla commercial scanners have become available, providing improved signal-to-noise ratio and thus allowing the detection of smaller signal changes following activation.

However, in fMRI, image characteristics are strictly dependent on not only the hardware technology of the MR instrumentation, but also on the specific acquisition sequence available on the scanner. A major prerequisite for fMRI imaging quality is the need for short acquisition time, since a significant loss of signal can occur due to motion artefacts produced by both the physiological motion originated by the brain's pulsation with the cardiac cycle and the involuntary motion of the subject's head. To comply with this requirement, the pulse sequence usually adopted to acquire fMRI data (on 1.5 Tesla or 3 Tesla scanners) is the 2D single-shot echo-planar imaging (EPI) ${ }^{[20]}$. This sequence allows for a fast acquisition of the whole brain volume (1-4 sec), with the additional advantage of presenting an excellent BOLD sensitivity and high efficiency in terms of signal to noise ratio per unit of time ${ }^{[21]}$. One limitation is that images acquired with EPI are affected by some artefacts, such as a geometric distortion (in proportion to magnetic field), and physiological noise, superimposed on the signal. Based on 3D acquisition schemes, other pulse sequences have been proposed for BOLD fMRI, with the aim of reducing acquisition time, thus improving temporal resolution ${ }^{[22,23]}$. Among these, the 3D PRESTO sequence has been recently compared with 2D single-shot EPI by Barry et al. ${ }^{[21]}$, who concluded that this sequence is preferable to 2D EPI for whole brain fMRI on 7 Tesla scanners, thanks to the reduction of geometrical distortions and physiological noise, as well as the expanded volume coverage.

Two additional considerations should be pointed out on the image characteristics of fMRI BOLD:

- With the modern scanners and sequences, spatial resolution of BOLD fMRI can reach $1 \mathrm{~mm}$; however a typical spatial resolution of $2 \mathrm{~mm}-3 \mathrm{~mm}$ is generally obtained, as a trade-off between acquisition time and the size of brain volume to be acquired. Moreover the BOLD response is not perfectly localized in the spot of neural activation, as it is generated by the hemodynamic response at capillary level.

- Although acquisition time on the order of $40 \mathrm{msec}$ or less is possible, temporal resolution of fMRI is intrinsically limited by the dynamic characteristics of the hemodynamic response, which rises 2-3 sec after neural activation and return to baseline after $10 \mathrm{sec}^{[24]}$.

\subsection{2 fMRI Activation studies}

An fMRI BOLD study usually consists of a series of fMRI acquisitions, taken with the subject lying on the scanner bed in a resting state or during an activated state. The activated state, which generates the brain response of interest, is obtained by stimulating the subject using specific cues.

In fMRI studies relative to the investigation of gut-brain interaction, activate states were obtained by administration of substances, like oral glucose load ${ }^{[25-27]}$ or direct hormone infusion ${ }^{[28]}$, or combination of visual cues (high palatable food versus non-food pictures) and hormone infusion ${ }^{[29-32]}$. Many other studies used pure visual stimuli, like food/non-food pictures (see for example ${ }^{[33]}$ ), or taste-olfactory stimuli (see for example ${ }^{[34,35]}$ ), to compare hungry and satiated states.

After acquisition, fMRI images need to be processed in order to identify the brain regions involved in functional activation. Intuitively, these areas could be detected by a simple voxel-by-voxel subtraction between images acquired 
during the stimulation and those obtained during the resting state; in practice, due to the low level of activation signals with respect to the brain background activity and image noise, fMRI analysis is typically performed using sophisticated statistical methods, capable of generating statistical brain maps of activation, which represents the brain response of a single individual or a group of individuals to a specific cue.

\subsection{3 fMRI image analysis}

The more diffused method for fMRI image analysis is Statistical Parametric Mapping (SPM), originally proposed by Friston et al. in $1995^{[36]}$. SPM is configured as a free software package and is available from web (http://www.fil.ion.ucl.ac.uk/spm). Other similar software packages, commonly used for statistical analysis of fMRI data and available on web for research groups, are FMRIB Software Library (FSL) (available at: http://www.fmrib.ox.ac.uk/fsl/) developed by the analysis group of the Oxford University, UK ${ }^{[37,38]}$ and AFNI, developed at NIMH, in Bethesda, USA (available at: http://afni.nimh.nih.gov/afni) ${ }^{[39,40]}$.

\subsection{PET}

PET produces images of radioactivity distribution in selected body sections of the patient under examination, following the administration of a radiopharmaceutical, labelled with a positron emitter isotope. The positron emitters commonly used in PET $\left({ }^{11} \mathrm{C},{ }^{13} \mathrm{~N},{ }^{15} \mathrm{O},{ }^{18} \mathrm{~F}\right)$ are isotopes of elements constituent of the biological matter; therefore, in principle, with these isotopes, all molecules present in the human body could be labelled, thus providing physiological radioactive molecules, able to track biochemical and physiological processes in vivo ${ }^{[16]}$.

\subsubsection{PET acquisition: technical aspects}

A positron, emitted by a radioactive nucleus in the human body, travels a short distance losing its kinetic energy, through the surrounding matter. Then it interacts with a particle with the same mass and opposite charge (an electron in the matter), generating an annihilation event in which the masses of positron and electron disappear and an electromagnetic radiation (two $511 \mathrm{keV}$ gamma rays emitted $180^{\circ}$ to each other) is formed. These gamma rays are detected in PET, indirectly allowing the detection of the positron decay.

A PET tomograph consists of a ring of detectors surrounding the organ under study and connected via temporal coincident circuitry. One event is recognized when two gamma rays are detected simultaneously or within a very short time interval (on the order of nsec) by a pair of detectors in the ring. The line connecting the centres of the two detectors is recognized as the line along which the annihilation has occurred. During PET scanning, radioactivity in the body is sampled at different linear and angular positions to generate a set of activity profiles at different projections angles ${ }^{[41]}$. These are the input for the reconstruction algorithm, which generates the tomographic images representing the radioactivity distributed in the body sections of interest ${ }^{[42]}$.

PET scanners of the current generation are provided with several adjacent rings of detectors generating multiple slices and allowing a simultaneous $3 \mathrm{D}$ representation of the radioactivity in the body. The 3D sampling of the radioactivity distribution significantly increases the sensitivity of the technique (by a factor of 5-10) ${ }^{[43]}$.

The significant improvements of the modern PET scanners in both hardware and software components also result in PET image spatial resolution on the order of $3 \mathrm{~mm}$, thus close to the intrinsic spatial physical uncertainty of the positron annihilation detection ${ }^{[44]}$.

In the study of the functional activity of the brain, an important limiting factor is also represented by temporal resolution. This is defined as the minimum time to detect signal, and it is on the order of minutes in PET; short scanning time would generate, in fact, data with excessive noise. However temporal resolution is also related to the minimum time between two subsequent scans, thus also depending on the radioisotope physical half-life and on the kinetics of the molecules in the body. 


\subsubsection{PET activation studies}

Activation studies with PET were developed before the exploitation of BOLD effect in MRI. Their application have been progressively reduced in favour of fMRI methodology, which offers better performance in terms of both spatial and temporal characteristics; however in the study of CNS control on food intake, PET activation studies have been widely carried out ${ }^{[13,45-47]}$, even recently ${ }^{[48,49]}$.

A PET activation study usually employs water molecules, labelled with the positron-emitter radioisotope ${ }^{15} \mathrm{O}$. The radioactive tracer is injected intravenously as $\mathrm{H}_{2}{ }^{15} \mathrm{O}$, or inhaled as $\mathrm{C}^{15} \mathrm{O}_{2}$ or ${ }^{15} \mathrm{O}_{2}$. The radioactive water crosses the blood-brain barrier and can be used as a marker of regional cerebral blood flow (rCBF). In fact, local flow increases in brain areas involved in functional activity, thus leading to an augmented uptake of $\mathrm{H}_{2}{ }^{15} \mathrm{O}$ into brain tissue at those sites ${ }^{[50]}$.

Activation PET studies on food intake control usually compare rCBF in fed or fasted conditions ${ }^{[45-47]}$. The acquisition protocols in PET is also very similar to those in fMRI (subsequent acquisitions during rest and during a task, in fasted or fed conditions); however, in PET, each acquisition should be preceded by an injection of radiotracer, this fact limiting the number of different activations in a single experiment, due to dosimetry constraints. Moreover the need of more than one injection of the tracer limits temporal resolution of repeated PET blood flow studies, because, before performing a second scan and injecting a new radioactivity dose, the previous activity of ${ }^{15} \mathrm{O}$ should be decayed (10-12 minutes).

The analysis of PET activation images follows the same approach described for fMRI; however, in PET studies, it is necessary to use groups of subjects rather than single subjects, due to the low signal to noise ratio of PET images and the limited number of scans per subject; therefore, in this context, the use of statistical methods is mandatory to extract reliable brain activation maps, by pooling together data acquired from different individuals.

\subsubsection{PET neurotransmission studies}

A peculiarity of PET methodology is its capability to detect regional distribution of neuroreceptors and neurotransmitters, thus allowing the investigation of the neuroreceptor-ligand machinery involved in food intake regulation. In particular, studies have been addressed in clarifying the role of dopaminergic and mu-opioid systems in the control of food intake.

In PET, the dopamine system has been investigated using ${ }^{11} \mathrm{C}$-raclopride, a radioactive tracer that binds to dopamine D2 receptors ${ }^{[51-53]}$. The tracer is usually injected intravenously as a bolus, and a dynamic PET scan (subsequent PET acquisitions) is performed to sample the variations in brain tracer concentration, starting at the injection time up to 60 minutes. The dynamic behaviour of the tracer in the body can be thus studied, using the classical compartmental models employed in pharmacokinetics ${ }^{[54]}$. In this way, parameters characterizing tracer kinetics can be derived, in particular the blood-to-tissue transport constant, the distribution volume and the binding potential, this last directly related to the receptors' availability. The quantitation of these parameters needs arterial blood samples, acquired simultaneously during PET scan, to assess the tracer concentration in the plasma and to use it as the input function of the compartmental model. However, this procedure is invasive, requiring arterial catheterization of the subject under study. According to a modified compartmental model ${ }^{[55]}$, to avoid arterial sampling, the measurement of the tracer concentration in a cerebral region lacking of the studied receptors used as a reference region is substituted to the measurement of the tracer concentration in arterial blood. As the estimation of compartmental models is cumbersome from the mathematical point of view, the assessment of receptor kinetic parameters is very often carried out using simplified graphical approaches, which allow fast and reliable estimates of the receptor's binding potential ${ }^{[56,57]}$.

PET human studies on the mu-opioid receptor system are aimed at exploring the role of brain reward and affective mechanisms ${ }^{[58]}$. At present only few studies on the role of this system in food regulation have been published ${ }^{[59]}$, although this field of research is rapidly growing. Mu-opioid PET studies are based on the intravenous injection of a bolus of ${ }^{11} \mathrm{C}$-carfentanil, a selective mu-opioid receptor radiotracer, and a PET dynamic scan, usually consisting of subsequent 
acquisitions starting at the injection time up to 100 minutes ${ }^{[58]}$. The availability of mu-opioid receptors in the different brain areas can be assessed with the same methodology employed for D2 receptors, using compartmental models and the simplified graphical analysis approach ${ }^{[58,59]}$.

\subsection{Anatomical localization of fMRI and PET functional images}

PET and fMRI are suitable for the imaging of physiological and biochemical processes within different brain regions, but do not intrinsically show the underlying anatomic features of the involved structures. Therefore, an important aspect in fMRI and PET analysis is the localization of functional areas on brain anatomy to correctly identify the corresponding cerebral structures. This problem can be solved with realignment of functional images to anatomical images, by means of image registration procedures, which achieve a pixel by pixel correspondence between anatomy and function. The registration process consists in the identification of the spatial reference systems in which each image study is represented and in the determination of the geometrical transformation to remap one study into the other.

In the case of an fMRI or PET study of a single subject, we can directly register functional data to the morphological data of the same subject, acquired by anatomical MRI. We can make the assumption that the head is a rigid body; therefore the spatial transformation is completely defined by a roto-translation and can be computed with rigid registration techniques ${ }^{[60]}$.

When the study involves a group of subjects, functional fMRI/PET data are usually remapped to a common reference space, which provides the morphological correlate. The most used spatial reference for fMRI/PET analysis is the reference space, introduced by the Montreal Neurological Institute (MNI) (http://www.bic.mni.mcgill.ca/) and based on the classical cerebral stereotactic atlas defined by Talairach and Tornoux ${ }^{[61]}$. Remapping between a single subject brain and the common reference space requires the use of deformable registration techniques, based on non-linear spatial transformation in order to take into account inter-subject brain anatomical variability ${ }^{[62]}$.

\subsection{Comparative technical considerations and limitations}

In the evaluation of potentiality of the different imaging techniques to study CNS control on food intake, some essential physical features of the different instrumentations available must be considered.

Spatial resolution is of obvious importance in the examination of any organ, but in the case of brain studies, it becomes essential to differentiate contiguous, yet distinct anatomical-functional structures. From this point of view, fMRI is slightly superior to PET, with a resolution of $1.8 \mathrm{~mm}-2 \mathrm{~mm}$ compared to a PET resolution of $3 \mathrm{~mm}-4 \mathrm{~mm}$. In general, in the specific context of CNS control of food intake, spatial resolution of neuroimaging techniques is an important limiting factor for imaging micro-anatomical structures, such as brainstem or hypothalamus; this limitation is likely the cause of the discrepancies between experimental findings in studies on gut-brain interactions, as recently suggested by Gibson et al. in their review on this subject ${ }^{[63]}$.

Another limiting factor of PET with respect to fMRI is the poor temporal resolution. For this reason, activation PET images with ${ }^{15} \mathrm{O}$, which can be acquired every 10 minutes, could be employed to study slow processes, for example a fed condition with respect to a fasted one, thus indirectly measuring the satiating efficiency of a food. On the contrary, fMRI, with higher temporal resolution, is also suitable to follow faster dynamic processes, such as neural activity related to meal termination ${ }^{[64]}$.

Moreover, also the invasiveness of the technique should be carefully considered. PET poses the problem of radiation exposure, although the increased detection efficiency in current 3D PET technology permits a reduction of the amount of radioactivity administered to the subject. On the contrary, fMRI could be used without limits in repeatability, being a totally non invasive method. In fact it is based on endogenous contrast mechanisms and does not require administration of external contrast agents. 
A powerful peculiarity of PET consists in its imaging capability of neurotransmission circuits such as dopaminergic and mu-opioid receptor systems at molecular level.

Table 1 summarises the main characteristics of techniques suitable for functional brain imaging in human subjects.

Table 1. Characteristics of techniques suitable for functional brain imaging investigation

\begin{tabular}{llllll}
\hline Technique & Image contrast & Image content & Spatial resolution & Temporal resolution & Invasiveness \\
\hline \multirow{2}{*}{ fMRI } & $\begin{array}{l}\text { Endogenous } \\
\text { (BOLD effect) }\end{array}$ & $\begin{array}{l}\text { Cerebral Activation (Local } \\
\text { variation of oxygenated blood } \\
\text { haemoglobin) } \\
\text { Cerebral Activation (local }\end{array}$ & $1 \mathrm{~mm}-2 \mathrm{~mm}$ & Seconds & No \\
& $\begin{array}{l}\text { Exogenous } \\
\text { (Radiotracers of } \\
\text { cerebral blood flow) }\end{array}$ & $\begin{array}{l}\text { variation of regional blood } \\
\text { flow) }\end{array}$ & $3 \mathrm{~mm}-4 \mathrm{~mm}$ & Minutes & Yes \\
PET & $\begin{array}{l}\text { Exogenous } \\
\text { (Radiotracers of } \\
\text { neuroreceptors/ } \\
\text { neurotrasmitters) }\end{array}$ & $\begin{array}{l}\text { Neuroreceptors binding } \\
\text { potential }\end{array}$ & $3 \mathrm{~mm}-4 \mathrm{~mm}$ & Minutes & Yes \\
& & & & \\
\hline
\end{tabular}

\section{Brain circuits involved in food regulation and peripheral signals related to nutritional status}

Since the pioneering study by Tataranni et al. ${ }^{[65]}$, disclosing the enormous potentiality of functional neuroimaging in exploring the human brain circuits associated with the cognitive functions involved in nutritional control, it has been shown that numerous different regions of the brain participate in the regulation of hunger and satiation. In fact, using a PET procedure with 15O-labelled water to measure $\mathrm{rCBF}$, as a marker of neuronal activity, these Authors reported that an increased $\mathrm{rCBF}$ in the vicinity of the hypothalamus and insular cortex and in additional paralimbic and limbic areas (orbitofrontal cortex, anterior cingulate cortex, and parahippocampal and hippocampal formation), thalamus, caudate, precuneus, putamen, and cerebellum is associated with hunger, whereas satiation involved increased rCBF in the vicinity of the ventromedial prefrontal cortex, dorsolateral prefrontal cortex, and inferior parietal lobule. This important study revealed also that insulin and free fatty acids may be metabolic modulators of postprandial brain neuronal events.

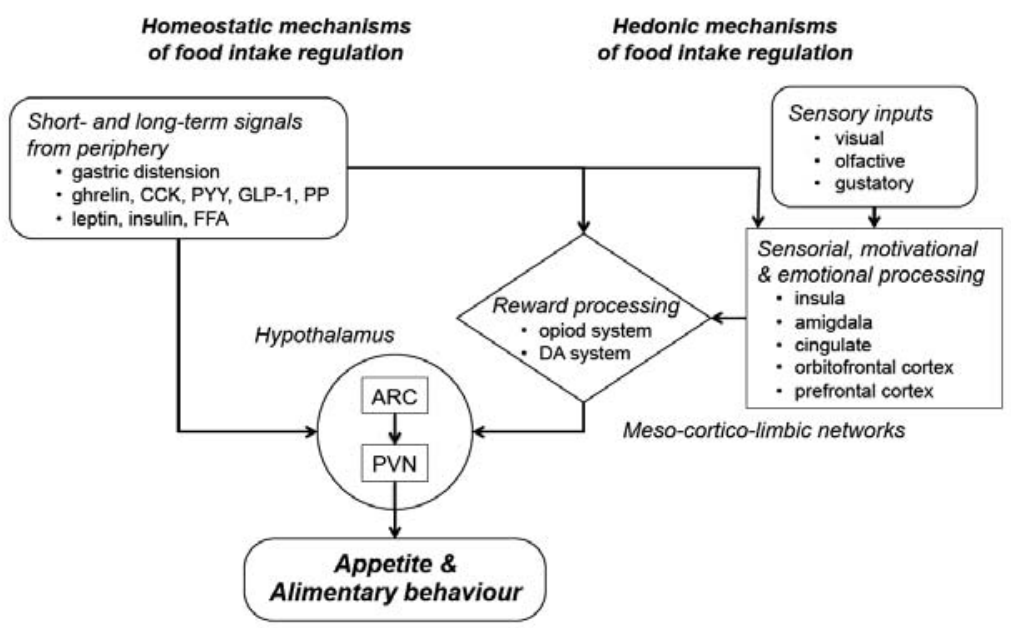

Figure. Schematic representation of neural mechanisms controlling appetite and alimentary behaviours in relation to brain networks explored with neuroimaging techniques.

Note. CCK: cholecystokinin; PYY: peptide YY; GLP-1: glucagon-like peptide-1; PP: pancreatic polypeptide; FFA: free fatty acids; ARC: hypothalamic arcuate nucleus; PVN: hypothalamic paraventricular nucleus; DA: dopamine. 
To provide adequate nutrition, it is important for the CNS to have specific circuitry that regulates the levels of nutrients in the blood and in the body stores, according to a homeostatic mechanism. However in the recent years, under the pressure of the rapid changes of food environments in post-industrial societies, a growing understanding that the ingestive behaviour is also largely determined by non-metabolic factors, has led to the distinction between homeostatic and hedonic eating ${ }^{[1-3,9]}$. A schematic representation of the brain structures and networks involved in processing of signals relevant for appetite and eating behaviours is presented in the figure.

In spite of the fact that homeostatic drive for feeding is not intrinsically related to the rewarding aspects of the behaviour, the avoiding of the discomfort associated with hunger provides a strong drive for feeding, and the feeling of satisfaction that accompanies a full stomach may itself be rewarding. Thus, although different neural circuits support the various homeostatic and hedonic sensory mechanisms that underlie the control of food intake, the boundary between them is not completely clear-cut.

\subsection{Homeostatic mechanisms for food intake regulation}

\subsubsection{Central structures}

The hypothalamus plays a significant role in the regulation of feeding and body weight maintenance ${ }^{[8,66,67]}$. It is subdivided into nuclei, and, among these, the arcuate nucleus of the hypothalamus (ARC) acts as the site of integration of a number of neural and blood-borne signals. Two major subpopulations of neuron in the ARC are prominently implicated in the regulation of food intake. One population, co expressing cocaine- and amphetamine-related transcript (CART), pro-opiomelanocortin (POMC), and the related derivative, $\alpha$-melanocytestimulating hormone ( $\alpha$-MSH), inhibits food intake. The second population of neurons increases food intake by co-expressing neuropeptide Y (NPY) and agouti-related protein (AgRP). Both populations project to areas important in the regulation of food intake, such as the hypothalamic paraventricular nucleus $(\mathrm{PVN})$ and ventromedial nucleus $(\mathrm{VMN})$ which regulate also a number of functions, including pituitary hormone secretion and appetite. Their destruction results in hyperphagia and weight gain. Furthermore, microinjection of orexigenic neuropeptides (such as NPY and AgRP) into the PVN stimulates food intake, whereas anorectic agents such as $\alpha$-MSH inhibit feeding ${ }^{[8,66]}$. The hypothalamic involvement after an oral glucose load has been investigated with neuroimaging fMRI technique in humans by Matsuda et al. ${ }^{[25]}$. The Authors evidenced a significant deactivation in regions of the hypothalamus including the VMN and PVN with a temporal pattern starting 4 min after ingestion and lasting approximately $10 \mathrm{~min}$, which provided information about the lag time of homeostatic neural responses. The study also reported that obese participants showed a slower and smaller response, suggesting that delayed activation of satiety centres following glucose consumption may contribute to excessive intake in obese individuals. Similarly, Smeets at al., $2005^{[27]}$ using fMRI technique, reported that the hypothalamic deactivation in response to an oral load of glucose is dose-dependent, the larger signal decrease resulting from the larger glucose ingestion.

The brainstem is another key CNS appetite regulation centre ${ }^{[8,66]}$, and circulating factors may act directly on brainstem structures such as the area postrema (AP). There are extensive reciprocal connections between the brainstem and the hypothalamus, and the brainstem therefore has the potential to act as another site of integration between endocrine and neuronal signals.

Neurohormonal signals from the gut and adipose tissue converge on the hypothalamus where they are integrated, and in turn regulate energy intake and energy expenditure ${ }^{[10-12]}$. Cortical inputs in terms of emotional, social, and learned behaviour, as well as inputs from reward circuits (see below), including the mesolimbic dopaminergic system, all impact upon energy balance and communicate with the hypothalamus ${ }^{[68,70]}$.

\subsubsection{Signals from the periphery}

Leptin is an adipocyte-derived hormone capable of acting at the hypothalamic level to induce satiety. The plasma levels of leptin are positively correlated to the percentage of body fat and are also decreased by fasting. The leptin receptor is 
present in several brain sites, with the densest expression being found in the ventral basal hypothalamus, especially in the ARC, and lower levels in several extra hypothalamic sites, including the brainstem. Leptin responsive neurons in the ARC include both those containing NPY and AgRP and those containing POMC and $\alpha-\mathrm{MSH}$, as well as CART. While the POMC/CART neurons appear to be activated by the presence of leptin, the NPY/AgRP are inhibited. Thus leptin, as an adiposity signal, acts by shifting the balance from the potent feeding system constituted by the NPY/AgRP neurons toward the POMC/CART satiety system ${ }^{[8,10-12,66]}$. Neuroimaging of responses to food stimuli have confirmed such an action of leptin. In genetically leptin-deficient adults receiving leptin supplementation, Baicy et al. ${ }^{[30]}$ reported reduced fMRI activation in areas involved with hunger (insula, parietal and temporal cortex) and greater activation in regions linked to inhibition and satiety (prefrontal cortex) in response to visual pictures of food (e.g. fried chicken, cheeseburgers) compared to neutral stimuli (e.g. brick walls). In genetically leptin-deficient adolescents, one week of leptin administration markedly reduced fMRI activation in the ventral striatum in response to food images observed pre-treatment ${ }^{[31]}$. Rosenbaum et al. ${ }^{[32]}$ investigated obese individuals receiving injections of leptin or saline for five weeks. Postadministration, the saline group showed significantly greater fMRI activation to food cues compared to the leptin group in areas including the insula, parahippocampal gyrus, and middle and superior frontal gyri, consistent with relatively greater appetitive responsivity and drive to eat. Thus all neuroimaging studies are consistent with a model in which leptin down-regulates hedonic activation in reward areas in response to food cues, and simultaneously up-regulates homeostatic control by enhancing the central response to peripheral satiety signals.

The brain receives a wide variety of signals from the gastrointestinal tract, via either sensory afferents or via the circulation, which also function as short-term satiety signals and possibly long-term regulators of body weight. Afferent signals carried by the vagus nerve include indications of gastric stretch as well as a number of signals from gut hormones. Sensory terminals carrying this information terminate in the nucleus of the solitary tract, from where direct projections innervate several hypothalamic structures ${ }^{[10-12]}$.

Ghrelin is a powerful orexigen across a broad range of species, including humans. It is principally synthesized in endocrine cells of the stomach, and particularly found in the gastric fundus. Although widely expressed, the ghrelin receptor has been found in brain in areas involved in regulation of appetite and energy balance, including hypothalamic nuclei ${ }^{[71]}$. In ARC, NPY/AgRP neurons highly express ghrelin receptor, ghrelin inducing immediate activity in NPY neurons. Several studies have demonstrated pre-prandial plasma ghrelin elevations and these peaks correlated well with hunger scores, is therefore considered to have a potential role as a meal initiator and a critical signal to induce hunger during fasting. Ghrelin also appears to participate in long-term energy balance. In humans, ghrelin levels are inversely correlated with adiposity, being low in the obese, higher in lean subjects, and markedly elevated in subjects who are cachectic due to a diverse range of conditions. This has been interpreted as an adaptive response to restrain further overeating in the obese or to stimulate it in the underweight ${ }^{[11]}$.

Two fMRI studies measured the brain activation in processing pictures of food in relation with ghrelin levels. In the study conducted by Malik et al. ${ }^{[29]}$, the activation caused by the view of highly palatable foods pictures (like pizza and hamburgers) was compared with non-food stimuli (scenery pictures) following a 3-h fast in lean healthy, before and after a 20-min ghrelin infusion; post-infusion increases in response to the food (versus non-food) pictures were observed in the amygdala, orbitofrontal cortex, insula and striatum, comprising areas that are associated with encoding the reward value of stimuli. Also Kroemer et al. ${ }^{[71]}$ investigated the brain activation and the blood plasma levels of ghrelin in relation to palatable food pictures in fasting subjects versus sated ones, and found a direct correlation between high fasting ghreling levels and increase of brain activation and subjective appetite ratings.

Overall, these findings suggest that the orexigenic effect of ghrelin is associated with an up-regulation of mesolimbic dopaminergic activity accompanied by an increase in motivational salience of high-energy foods (see below). 
Gastric loads by itself stimulate vagal mechanosensitive fibres which may be thus responsible for the suppression of meal size and feeding induced by gastric loads confined to the stomach, independently of the nutrient content of the load. However, the effect of gastric distension alone is insufficient to account for all aspects of postprandial satiety ${ }^{[10,11]}$. Nonetheless moderate gastric distension was reported to be associated with fMRI activation of sensorimotor cortices and right insula, whereas a more pronounced distension additionally involved left posterior amygdala, left posterior insula and the left precuneus ${ }^{[72]}$, evidencing the participation of satiety circuits in response to gastric distension.

Cholecystokinin (CCK) is mainly synthesized in the duodenum and jejunum. It is rapidly released into the surrounding tissues and circulation in response to nutrients in the gut, in particular, fat and protein-rich meals. Its action of inhibiting food intake and producing a sensation of satiety is exerted at CCK receptors found on vagal afferent neurons as well as in the brain in the nucleus of the solitary tract, midbrain and hypothalamus ${ }^{[10,11]}$.

Peptide YY (PYY) is another recently recognized gut hormone potentially playing a role in feeding regulation. It is released by enteroendocrine cells throughout the entire gastrointestinal tract, but particularly in the distal part, and it inhibits food intake in rodents and humans. PYY is secreted into the circulation following meals and suppressed by fasting, a pattern depicting a mirror image of that found for ghrelin ${ }^{[10,11]}$. Using fMRI neuroimaging in lean healthy subjects, Batterham et al. ${ }^{[28]}$ elegantly contrasted the infusion of PYY at physiologically relevant doses mimicking a fed state with saline infusion in fasting conditions, and found that the greatest modulatory effect of PYY is exerted on left caudolateral orbitofrontal cortex as well as in within the limbic system (insula and anterior cingulate cortices) and ventral striatum (globus pallidus and putamen). Correlations of changes in brain activity with post-infusion feeding behaviour showed that subsequent caloric intake correlated with activation changes in the hypothalamic region after saline infusion but with orbital frontal cortex after PYY infusion, and the Authors concluded that the presence of a postprandial satiety factor switches food intake regulation from a homeostatic to a hedonic, corticolimbic area.

Glucagon-like peptide-1 (GLP-1) and oxyntomodulin are products of the proglucagone gene and are released postprandially from intestinal cells in proportion with the amount of energy ingested, acting as satiety signals. GLP-1 is clinically intensively investigated for its anti-diabetic effect associated with the tendency to reduce body weight ${ }^{[10,11]}$. A PET study in adult males and females measuring rCBF during oral administration of a liquid formula meal until satiation ${ }^{[73]}$ revealed a significant associations between postprandial GLP-1 levels and increases in activation in the dorsolateral prefrontal cortex and hypothalamus. Nonetheless, since the dorsolateral prefrontal cortex is involved in controlling inappropriate behavioural responses and has been associated with both food reward and satiety, it is unclear whether activation in this area reflects motivation to eat or inhibition of intake.

Pancreatic polypeptide (PP) is principally secreted by a population of cells in pancreatic islets. It is released into the circulation in response to nutrient ingestion and is subject to control by the vagus nerve and a number of other factors. PP reduces food intake when administered to rodents and humans, although its role in the regulation of energy balance is still unclear $^{[10,11]}$.

\subsection{Hedonic mechanisms for food intake regulation}

Several brain systems for food reward are involved in the hedonic regulation of eating behaviour, which relies on the interaction of the complex neural processes implicated in sensation, pleasure reaction (liking) and motivation (wanting), as well as higher order processes such as learning, memory, planning and prediction in order to give rise to conscious experience of the hedonic pleasure beside the sensory properties of the food ${ }^{[1,3,74]}$.

Sensory systems - Olfactory, gustative, visual and somatosensory polymodal representation of food, after primary cortical and higher order processing of the specific sensorial modality, is relayed to posterior orbitofrontal cortex, amigdala and ventral striatum, including the nucleus accumbens. The role of the prefrontal cortex in taste cognitive processing for 
guiding complex motivational tasks has been elegantly demonstrated by Kringelbach et al. ${ }^{[75]}$ in humans with fMRI, whereas Gottfried et al. ${ }^{[76]}$ with fMRI evidenced the involvement of human amygdala and orbitofrontal cortex in reward representation in the presence of olfactory cues during appetitive conditioning.

It is remarkable that brain responses to different sensory food cues have been shown to be significantly altered in obese individuals. Abnormal responses to visual stimuli related to the alimentary experience have been observed in obese individuals with imaging techniques in a broad range of brain networks involved in reward and emotional memory. Rothemund et al. ${ }^{[77]}$ reported with a fMRI investigation that, compared with normal weight counterparts, obese women selectively activate regions associated with reward anticipation and habit learning (dorsal striatum) in response to stimulation with pictures of high-calorie foods and show a comparatively enhanced activity in circuits related to taste processing (insula), motivation (orbitofrontal cortex) and emotions/memory (posterior cingulate). Consistently, Martin et al. ${ }^{[78]}$ used fMRI to detect a higher pre-meal activation in anterior cingulate cortex and medial prefrontal cortex of obese individuals vs. non-obese when observing pictures of high-calorie aliments, and concluded that food motivation differs in obese and lean adults.

Also food related olfactive experience in obese subjects has been found to be associated to abnormal brain responses. In a small sample of obese subjects compared with normal-weight individuals, Bragulat et al. ${ }^{[79]}$ evidenced with fMRI technique a greater response to four food-related odours in bilateral hippocampus/parahippocampal gyrus. Interestingly, brain circuits activated by food olfactive cues are similar to those triggered by odorous stimuli of addictive substances, like alcohol.

Moreover, DelParigi et al. ${ }^{[80]}$, using a PET based technique and labelled water to measure changes in $\mathrm{rCBF}$, found that obesity is associated with an abnormal brain response to the sensory aspects of a liquid meal after a prolonged fast, especially in areas of the primary gustatory cortex. Accordingly, in more recent studies ${ }^{[6,68]}$ an irregular activation in a range of regions involved in hedonic food intake has been observed, which suggests an increased central sensitivity to palatable food in obese individuals.

Reward systems - Several brain areas involved in the reinforcement of responses without a significant homeostatic value have been identified in the recent years. The mechanisms contributing to reward can be subdivided into distinguishable processes supported by different neural circuits and neurotransmitters. So, the processes of liking (or emotion and affect in response to sensation), wanting (or motivation) and learning can be recognized, each having an explicit (or subjective, conscious) and an implicit (or objective, unconscious) component and involving particular neural structures ${ }^{[74]}$.

Reward-related learning has been shown to involve many different brain areas and pathways involving the dopaminergic system which includes the ventral striatum and the tegmental midbrain. The mesolimbic dopamine system with its projections from the ventral tegmental area to the nucleus accumbens together with neural circuits involving the prefrontal cortex, amygdala, and hypothalamus is crucial in the incentive motivational state and in the prediction error in reward learning (more related to motivation for immediate action associated with alimentary "wanting" rather to the hedonic value of the reward itself, entailed in food "liking") ${ }^{[81]}$.

Neuroimaging studies in humans have confirmed the role of dopamine in reward learning with indications of dopamine release in the ventral striatum which has also been shown to be active in the human brain in the prediction and the expectation of taste reward.

Using fMRI, O'Doherty et al. ${ }^{[82]}$ evidenced the central role of dopamine in mediating anticipation of reward to visual stimuli reliably predicting the subsequent delivery of a differently pleasant sweet taste, dopaminergic areas, such as the midbrain, amygdala, and ventral striatum (nucleus accumbens), showing the highest activity in anticipation. Similarly using fMRI, Berns et al. ${ }^{[83]}$ showed that the activity for rewarding stimuli in both the nucleus accumbens and medial orbitofrontal cortex was modulated by the predictability of the subsequent oral delivery of pleasurable stimuli. Hunger, in 
particular, has been shown to increase the response to the sight of food in some of these limbic/paralimbic areas: greater responses were elicited in the amygdala, parahippocampal gyrus, and anterior fusiform gyrus when participants were in a hungry state relative to a satiated state ${ }^{[84]}$.

Interestingly, Wang et al. ${ }^{[51]}$ reported that abnormalities in dopaminergic transmission can be evidenced in obese individuals. Using PET and a specific ligand for the dopamine type 2 receptor (D2), they found that the availability of D2 is decreased in the dorsal striatum of obese individuals, a neurochemical feature previously associated with other reward deficiency syndromes, like as drug addiction and gambling.

Several studies have suggested that food and drug rewards may share common neural structures and neurotransmitters which include the opioid receptor system according with the hypothesis that activation of ventral striatal opioids specifically encodes positive affect induced by tasty and/or calorically dense foods (such as sugar and fat), and promotes behaviours associated with this enhanced palatability ${ }^{[85]}$. Thus, the pleasure, hedonic impact, or "liking" of tasty foods should not be mediated by dopamine transmission in the nucleus accumbens, but rather by mu-opioid transmission in a distributed neural network including the nucleus accumbens, ventral pallidum, parabrachial nucleus, and nucleus of the solitary tract ${ }^{[74,78]}$. Using PET neuroimaging technique, mu-opioid availability has been reported ${ }^{[59]}$ to be reduced in different brain regions of obese subjects including caudate nucleus, hypothalamus and prefrontal cortex, according to a pattern observed also in brain regions of recently abstinent alcohol-dependent individuals, further suggesting that obesity could be possibly considered as a reward deficiency syndrome.

A recent study of Davis et al. ${ }^{[86]}$ highlights, throughout the targeting of functional polymorphism of the mu-opioid receptor (OPRM1) gene, the high involvement of mu-opioid in the bio-behavioural differences among obese, influencing the individual proneness to binge eating. In contrast to the motivation-independent representations of gustatory and olfactory stimuli, exploring with neuroimaging technique in humans the brain regions responding to taste intensity and taste affective valence, Small et al. ${ }^{[87]}$ observed a preferential response to pleasant compared with unpleasant taste in the orbitofrontal cortex with the right caudolateral orbitofrontal activation. Another study with fMRI neuroimaging showed that subjective ratings of taste pleasantness (but not intensity) correlate with activity in the orbitofrontal cortex and in the anterior cingulate cortex ${ }^{[88]}$.

Kringelbach et al. ${ }^{[89]}$ showed that a region of the left orbitofrontal cortex presented not only a sensory-specific decrease in the reward value to the whole food eaten to satiety, but also a correlation with pleasantness ratings, indicating that the reward value of the taste, olfactory, and somatosensory components of a whole food is actually represented in the orbitofrontal cortex. Another multimodal concordant evidence was coming from a PET study investigating the non-specific satiation effects of chocolate (with both olfactory and gustatory components) which found a correlation between the decrease in pleasantness and activity in the orbitofrontal cortex ${ }^{[90]}$.

The robust activation at the level of orbitofrontal cortex and meso-corticolimbic structures, observed through fMRI neuroimaging in relation to the top-down inhibition of food intake, indicates their involvement in the active modulation of desire for food, as shown in the study of Hollmann et al. ${ }^{[91]}$.

Thus, several evidences from neuroimaging studies using multi-modal combinations of taste and smell indicate that orbitofrontal cortex is consistently correlated with the subjective pleasantness of the alimentary cues, beside being consistently involved in the hedonic processing of other different rewarding reinforcers such as music, facial attractiveness, pain avoidance or monetary reward, and it is a very strong candidate for the mediation of the hedonic experience.

In Table 2, the studies investigating the different brain structures involved in processes relevant for alimentary activity are summarised on the basis of the presented functional stimulus or the neuroreceptor availability. 
Table 2. Summary of functional imaging studies for the investigation of brain structures involved in eating-related processes

\begin{tabular}{|c|c|c|c|c|c|}
\hline Ref no. & Authors & Year & Technique & Stimulus & Involved area / Findings \\
\hline \multicolumn{6}{|c|}{ Activation Studies } \\
\hline \multicolumn{6}{|c|}{ Visual stimulation } \\
\hline 84 & $\begin{array}{l}\text { LaBar KS, } \\
\text { et al. }\end{array}$ & 2001 & fMRI & food vs non-food visual cues & $\begin{array}{l}\text { amygdala, parahippocampal gyrus. and anterior fusiform } \\
\text { gyrus }\end{array}$ \\
\hline 82 & $\begin{array}{l}\text { O'Doherty } \\
\text { JP, et al. }\end{array}$ & 2002 & fMRI & $\begin{array}{l}\text { visual food cues, taste } \\
\text { conditioning }\end{array}$ & $\begin{array}{l}\text { dopaminergic midbrain, posterior dorsal amygdala, striatum, } \\
\text { orbitofrontal cortex }\end{array}$ \\
\hline 77 & $\begin{array}{l}\text { Rothemund } \\
\text { Y, et al. }\end{array}$ & 2007 & fMRI & visual food cues & dorsal striatum, insula, orbitofrontal cortex \\
\hline 30 & $\begin{array}{l}\text { Baicy } \mathrm{K}, \\
\text { et al. }\end{array}$ & 2007 & fMRI & $\begin{array}{l}\text { visual food cues, leptin } \\
\text { replacement }\end{array}$ & insula, parietal, temporal and prefrontal cortex \\
\hline 31 & $\begin{array}{l}\text { Faooqui IS, } \\
\text { et al. }\end{array}$ & 2007 & fMRI & $\begin{array}{l}\text { visual food cues, leptin } \\
\text { replacement }\end{array}$ & striatal regions \\
\hline 32 & $\begin{array}{l}\text { Rosenbaum } \\
\mathrm{M} \text {, et al. }\end{array}$ & 2008 & fMRI & $\begin{array}{l}\text { visual food cues, leptin } \\
\text { administration }\end{array}$ & $\begin{array}{l}\text { brainstem, culmen, parahippocampal gyrus, inferior and } \\
\text { middle frontal gyri, middle temporal, gyrus, and lingual gyrus } \\
\text { hypothalamus, cingulate gyrus, and middle frontal gyrus }\end{array}$ \\
\hline 29 & $\begin{array}{l}\text { Malik S, } \\
\text { et al. }\end{array}$ & 2008 & fMRI & $\begin{array}{l}\text { visual food cues, grelin } \\
\text { administration }\end{array}$ & amygdala, orbitofrontal cortex, anterior insula, striatum \\
\hline 78 & $\begin{array}{l}\text { Martin LE, } \\
\text { et al. }\end{array}$ & 2010 & fMRI & visual food cues & anterior cingulate cortex, medial prefrontal cortex \\
\hline 91 & $\begin{array}{l}\text { Hollmann } \\
\text { M, et al. }\end{array}$ & 2012 & fMRI & $\begin{array}{l}\text { visual food cues, inhibitory } \\
\text { cognitive reappraisal strategy }\end{array}$ & $\begin{array}{l}\text { dorsolateral prefrontal cortex, inferior frontal gyrus, } \\
\text { pre-supplementary motor area, dorsal striatum }\end{array}$ \\
\hline 71 & $\begin{array}{l}\text { Kroemer } \\
\text { NB, et al. }\end{array}$ & 2013 & fMRI & $\begin{array}{l}\text { visual food cues, glucose } \\
\text { ingestion }\end{array}$ & limbic and paralimbic regions \\
\hline 6 & $\begin{array}{l}\text { Cornier MA, } \\
\text { et al. }\end{array}$ & 2013 & fMRI & food vs non-food visual cues & insula, somatosensory cortex, parietal cortex, visual cortex \\
\hline \multicolumn{6}{|c|}{ Olfactory stimulation } \\
\hline 76 & $\begin{array}{l}\text { Gottfried JA, } \\
\text { et al. }\end{array}$ & 2003 & fMRI & visual/olfactory food cues & amygdala, orbitofrontal cortex \\
\hline 79 & $\begin{array}{l}\text { Bragulat } \mathrm{V} \text {, } \\
\text { et al. }\end{array}$ & 2010 & fMRI & olfactive food cues & bilateral hippocampus/parahippocampal gyrus \\
\hline \multicolumn{6}{|c|}{ Gustatory stimulation and satiation } \\
\hline 25 & $\begin{array}{l}\text { Matsuda M, } \\
\text { et al. }\end{array}$ & 1999 & fMRI & glucose ingestion & hypothalamus \\
\hline 83 & $\begin{array}{l}\text { Berns GS, et } \\
\text { al. }\end{array}$ & 2001 & fMRI & fruit juice vs water & nucleus accumbens, orbitofrontal cortex \\
\hline 90 & $\begin{array}{l}\text { Small DM, } \\
\text { et al. }\end{array}$ & 2001 & $\mathrm{PET} /{ }^{15} \mathrm{O}$ water & chocolate intake & $\begin{array}{l}\text { subcallosal region, orbitofrontal cortex, insula/operculum, } \\
\text { striatum and midbrain }\end{array}$ \\
\hline 87 & $\begin{array}{l}\text { Small DM, } \\
\text { et al. }\end{array}$ & 2003 & fMRI & gustatory food cues & cerebellum, pons, insula, amygdala, orbito-frontal cortex \\
\hline 89 & $\begin{array}{l}\text { Kringelbach } \\
\text { ML, et al. }\end{array}$ & 2003 & fMRI & $\begin{array}{l}\text { liquid foods with different } \\
\text { pleasantness }\end{array}$ & orbitofrontal cortex \\
\hline 88 & $\begin{array}{l}\text { de Araujo } \\
\text { IE, et al. }\end{array}$ & 2003 & fMRI & water with different solutes & rostral anterior cingulate cortex \\
\hline 75 & $\begin{array}{l}\text { Kringelbach } \\
\text { ML, et al. }\end{array}$ & 2004 & fMRI & liquid meal & orbitofrontal cortex, insula \\
\hline 80 & $\begin{array}{l}\text { DelParigi A, } \\
\text { et al. }\end{array}$ & 2005 & $\mathrm{PET} /{ }^{15} \mathrm{O}$ water & satiating liquid meal & $\begin{array}{l}\text { differences in obese vs lean subjects in insula, midbrain, } \\
\text { posterior cingulate, temporal, orbitofrontal cortices }\end{array}$ \\
\hline 73 & $\begin{array}{l}\text { Pannacciulli } \\
\mathrm{N} \text {, et al. }\end{array}$ & 2007 & $\mathrm{PET} /{ }^{15} \mathrm{O}$ water & satiating liquid meal & prefrontal cortex, hypothalamus \\
\hline 28 & $\begin{array}{l}\text { Batterham } \\
\text { RL, et al. }\end{array}$ & 2007 & fMRI & $\begin{array}{l}\text { PYY vs. saline infusion }+ \\
\text { post-infusion meal }\end{array}$ & $\begin{array}{l}\text { orbitofrontal cortex, insula, anterior cingulate cortices, } \\
\text { ventral striatum }\end{array}$ \\
\hline 72 & $\begin{array}{l}\text { Wang GJ, } \\
\text { et al. }\end{array}$ & 2008 & fMRI & gastric distension & sensorimotor cortices, insula, amygdala, insula, precuneus \\
\hline
\end{tabular}


Table 2. (continued.)

\begin{tabular}{|c|c|c|c|c|}
\hline Ref no. & Authors & Year & Technique & Involved area / Findings \\
\hline \multicolumn{5}{|c|}{ Neurotransmission Studies } \\
\hline 51 & $\begin{array}{l}\text { Wang GJ, } \\
\text { et al. }\end{array}$ & 2001 & $\begin{array}{l}\mathrm{PET} /{ }^{11} \mathrm{C} \\
\text { raclopride }\end{array}$ & $\begin{array}{l}\text { reduced striatal dopamine D2 receptor availability in obese vs } \\
\text { lean subjects }\end{array}$ \\
\hline 52 & $\begin{array}{l}\text { Haltia LT, } \\
\text { et al. }\end{array}$ & 2007 & $\begin{array}{l}\mathrm{PET} /{ }^{11} \mathrm{C} \\
\text { raclopride }\end{array}$ & $\begin{array}{l}\text { reduced striatal dopamine } \mathrm{D} 2 \text { receptor availability in } \\
\text { overweight/obese vs lean subjects }\end{array}$ \\
\hline 53 & $\begin{array}{l}\text { Volkow ND, } \\
\text { et al. }\end{array}$ & 2008 & $\begin{array}{l}\mathrm{PET} /{ }^{11} \mathrm{C} \\
\text { raclopride } \\
\mathrm{PET} /{ }^{18} \mathrm{~F} \text { FDG }\end{array}$ & $\begin{array}{l}\text { reduced striatal dopamine D2 receptor availability and } \\
\text { increased metabolism in somatosensory cortices (food } \\
\text { palatabilty) in obese vs lean subjects }\end{array}$ \\
\hline 59 & $\begin{array}{l}\text { Rota D, } \\
\text { et al. }\end{array}$ & 2008 & $\begin{array}{l}\mathrm{PET} /{ }^{11} \mathrm{C} \\
\text { carfentanil }\end{array}$ & $\begin{array}{l}\text { reduced } \mu \text {-opioid receptor availability in caudate nucleus, } \\
\text { hypothalamus and prefrontal cortex in obese vs lean subjects }\end{array}$ \\
\hline
\end{tabular}

\section{Conclusion}

In modern times, characterised by practically unlimited supplies of high-calorie food, hedonic mechanisms activated by presence of palatable food tend to override homeostatic systems activated by energy deficits in the control of human alimentary behaviour. The preferential activation of these systems associated to the hedonic reward of alimentation, considered beneficial in evolutionary development for ensuring consumption of relatively scarce, high-energy food sources in an unfavourable environment, is being recognized as a primary cause for the recent surge of obesity in modern societies worldwide.

Neuroimaging techniques, particularly suitable to study the functional integration of neural structures involved in food intake control and the associated cognitive processes, are a powerful tool to clarify fine interactions between the elements of this regulatory system. Therefore, these techniques provide a valuable help to achieve a more detailed comprehension of physiology underpinning alimentary behaviours and their derangements, and to detect multidisciplinary strategies against obesity which act directly or indirectly also on brain mechanisms involved in the control of food intake and energy balance.

\section{Acknowledgements}

The present work was partially financed by Progetto di Interesse del C.N.R. "Invecchiamento" and by project "Platform for International Collaborative Knowledge on Food Improvement Based on Ecological Resources (PICKFIBER)", funded by INTERREG IVC Programme, and partially appeared as a chapter in the project dissemination Handbook "Fibre, Organic Agriculture and Satiety”, printed by Arts Gràfiques Bobala - Editorial Milenio.

Sarah A. Tabozzi is presently supported by the project "PEGASO - PErsonalised GuidAnce Services for Optimising lifestyle management in teenagers through awareness, motivation and engagement", co-funded by the European Commission under the 7th Framework Programme.

\section{Conflict of interests statement}

The Authors declare that there is no conflict of interest that could be perceived as prejudicing the impartiality of the reported information.

\section{References}

[1] Lowe MR, Butryn ML. Hedonic hunger: a new dimension of appetite? Physiol Behav. 2007; 91: 432-439. PMid: 17531274. http://dx.doi.org/10.1016/j.physbeh.2007.04.006

[2] Berthoud HR. Metabolic and hedonic drives in the neural control of appetite: who is the boss? Curr Opin Neurobiol. 2011; 21: 888-996. PMid: 21981809. http://dx.doi.org/10.1016/j.conb.2011.09.004 
[3] Kringelbach ML. Food for thought: hedonic experience beyond homeostasis in the human brain. Neuroscience. 2004; 126: 807-819. PMid: 15207316. http://dx.doi.org/10.1016/j.neuroscience.2004.04.035

[4] Cornell CE, Rodin J, Weingarten HP. Stimulus-induced eating when satiated. Physiol Behav. 1989; 45: 695-704. http://dx.doi.org/10.1016/0031-9384(89)90281-3

[5] Rui L. Brain regulation of energy balance and body weight. Rev Endocr Metab Disord. 2013 Aug 30. [Epub ahead of print]. PMid: 23990408. http://dx.doi.org/10.1007/s11154-013-9261-9

[6] Cornier MA, McFadden KL, Thomas EA, Bechtell JL, Eichman LS, Bessesen DH, et al. Differences in the neuronal response to food in obesity-resistant as compared to obesity-prone individuals. Physiol Behav. 2013; 110-111: 122-128. PMid: 23313402. http://dx.doi.org/10.1016/j.physbeh.2013.01.002

[7] Berthoud HR. The neurobiology of food intake in an obesogenic environment. Proc Nutr Soc. 2012; 71: 478-487. PMid: 22800810. http://dx.doi.org/10.1017/S0029665112000602

[8] Saper CB, Chou TC, Elmquist JK. The need to feed: homeostatic and hedonic control of eating. Neuron. $2002 ; 36: 199-211$. http://dx.doi.org/10.1016/S0896-6273(02)00969-8

[9] Berthoud HR. Homeostatic and non-homeostatic pathways involved in the control of food intake and energy balance. Obesity (Silver Spring). 2006; 14 (Suppl 5): 197S-200S. PMid: 17021366. http://dx.doi.org/10.1038/oby.2006.308

[10] Chaudhri OB, Salem V, Murphy KG, Bloom SR. Gastrointestinal satiety signals. Annu Rev Physiol. 2008; 70: 239-255. PMid: 17937600. http://dx.doi.org/10.1146/annurev.physiol.70.113006.100506

[11] Wren AM, Bloom SR. Gut hormones and appetite control. Gastroenterology. 2007; 132: 2116-2130. PMid: 17498507. http://dx.doi.org/10.1053/j.gastro.2007.03.048

[12] Woods SC, Seeley RJ, Porte D Jr, Schwartz MW. Signals that regulate food intake and energy homeostasis. Science. 1998; 280: 1378-1383. PMid: 9603721. http://dx.doi.org/10.1126/science.280.5368.1378

[13] Del Parigi A, Gautier JF, Chen K, Salbe AD, Ravussin E, Reiman E, et al. Neuroimaging and obesity: mapping the brain responses to hunger and satiation in humans using positron emission tomography. Ann N Y Acad Sci. 2002; 967: 389-397. PMid: 12079866. http://dx.doi.org/10.1111/j.1749-6632.2002.tb04294.x

[14] Tataranni PA, DelParigi A. Functional neuroimaging: a new generation of human brain studies in obesity research. Obes Rev. 2003; 4: 229-238. PMid: 14649373. http://dx.doi.org/10.1046/j.1467-789X.2003.00111.x

[15] De Silva A, Salem V, Matthews PM, Dhillo WS. The use of functional MRI to study appetite control in the CNS. Exp Diabetes Res. 2012; 2012: 764017. PMid: 22719753. http://dx.doi.org/10.1155/2012/764017

[16] Phelps ME, Mazziotta JC. Positron emission tomography: human brain function and biochemistry. Science. 1985; $228: 799-809$. http://dx.doi.org/10.1126/science.2860723

[17] Berns GS. Functional neuroimaging. Life Sci. 1999; 65: 2531-2540. http://dx.doi.org/10.1016/S0024-3205(99)00297-0

[18] Ogawa S, Lee TM, Kay AR, Tank DW. Brain magnetic resonance imaging with contrast dependent on blood oxygenation.Proc Natl Acad Sci U S A. 1990; 87: 9868-72. PMid: 2124706. http://dx.doi.org/10.1073/pnas.87.24.9868

[19] Turner R, Le Bihan D, Moonen CT, Despres D, Frank J. Echo-planar time course MRI of cat brain oxygenation changes. Magn Reson Med. 1991; 22: 159-66. PMid: 1798390. http://dx.doi.org/10.1002/mrm.1910220117

[20] Mansfield P, Coxon R, Glover P. Echo-planar imaging of the brain at $3.0 \mathrm{~T}$ : first normal volunteer results. J Comput Assist Tomogr. 1994 May-Jun; 18: 339-43. PMid: 8188896. http://dx.doi.org/10.1097/00004728-199405000-00001

[21] Barry RL, Strother SC, Gatenby JC, Gore JC. Data-driven optimization and evaluation of 2D EPI and 3D PRESTO for BOLD fMRI at 7 Tesla: I. Focal coverage. neuroimage.2010.12.086. Epub 2011 Jan 11

[22] Song AW, Wong EC, Hyde JS. Echo-volume imaging. Magn Reson Med. 1994; 32: 668-71. PMid: 7808270. http://dx.doi.org/10.1002/mrm.1910320518

[23] Poser BA, Koopmans PJ, Witzel T, Wald LL, Barth M. Three dimensional echo-planar imaging at 7 Tesla. Neuroimage. 2010; 51: 261-6. PMid: 20139009. http://dx.doi.org/10.1016/j.neuroimage.2010.01.108

[24] Ogawa S, Menon RS, Kim SG, Ugurbil K. On the characteristics of functional magnetic resonance imaging of the brain. Annu Rev Biophys Biomol Struct. 1998; 27: 447-74. PMid: 9646874. http://dx.doi.org/10.1146/annurev.biophys.27.1.447

[25] Matsuda M, Liu Y, Mahankali S, Pu Y, Mahankali A, Wang J, et al. Altered hypothalamic function in response to glucose ingestion in obese humans. Diabetes. 1999; 48: 1801-1806. PMid: 10480611. http://dx.doi.org/10.2337/diabetes.48.9.1801

[26] Liu Y, Gao JH, Liu HL, Fox PT. The temporal response of the brain after eating revealed by functional MRI. Nature. 2000; 405: 1058-62. PMid: 10890447. http://dx.doi.org/10.1038/35016590

[27] Smeets PA, De Graaf C, Stafleu A, Van Osch MJ, Van der Grond J. Functional MRI of human hypothalamic responses following glucose ingestion. Neuroimage. 2005; 24: 363-8. PMid: 15627579. http://dx.doi.org/10.1016/j.neuroimage.2004.07.073 
[28] Batterham RL, Ffytche DH, Rosenthal JM, Zelaya FO, Barker GJ, Withers DJ, et al. PYY modulation of cortical and hypothalamic brain areas predicts feeding behaviour in humans. Nature. 2007; 450: 106-109. PMid: 17934448. http://dx.doi.org/10.1038/nature06212

[29] Malik S, McGlone F, Bedrossian D, Dagher A. Ghrelin modulates brain activity in areas that control appetitive behavior. Cell Metab. 2008; 7: 400-409. PMid: 18460331. http://dx.doi.org/10.1016/j.cmet.2008.03.007

[30] Baicy K, London ED, Monterosso J, Wong ML, Delibasi T, Sharma A, et al. Leptin replacement alters brain response to food cues in genetically leptin-deficient adults. Proc Natl Acad Sci U S A. 2007; 104: 18276-18279. PMid: 17986612. http://dx.doi.org/10.1073/pnas.0706481104

[31] Farooqi IS, Bullmore E, Keogh J, Gillard J, O'Rahilly S, Fletcher PC. Leptin regulates striatal regions and human eating behavior. Science. 2007; 317: 1355. PMid: 17690262. http://dx.doi.org/10.1126/science.1144599

[32] Rosenbaum M, Sy M, Pavlovich K, Leibel RL, Hirsch J. Leptin reverses weight loss-induced changes in regional neural activity responses to visual food stimuli. J Clin Invest. 2008; 118: 2583-2591. PMid: 18568078.

[33] Frank S, Laharnar N, Kullmann S, Veit R, Canova C, Hegner YL, et al. Processing of food pictures: influence of hunger, gender and calorie content. Brain Res. 2010; 1350: 159-66. PMid: 20423700. http://dx.doi.org/10.1016/j.brainres.2010.04.030

[34] Zald DH, Hagen MC, Pardo JV. Neural correlates of tasting concentrated quinine and sugar solutions. J Neurophysiol. 2002; 87: 1068-75. PMid: 11826070.

[35] O'Doherty J, Rolls ET, Francis S, Bowtell R, McGlone F, Kobal G, et al. Sensory-specific satiety-related olfactory activation of the human orbitofrontal cortex. Neuroreport. 2000; 11: 893-7. PMid: 10757540.

http://dx.doi.org/10.1097/00001756-200003200-00046

[36] Friston KJ, Holmes AP, Worsley KJ, Poline JP, Frith CD, Frackowiak RSJ. Statistical parametric maps in functional imaging: a general linear approach. Human Brain Mapping 1995; 2: 189-210. http://dx.doi.org/10.1002/hbm.460020402

[37] Smith SM, Jenkinson M, Woolrich MW, Beckmann CF, Behrens TEJ, Johansen-Berg H, et al. Advances in functional and structural MR image analysis and implementation as FSL. NeuroImage. 2004; 23(S1): 208-219. PMid: 15501092. http://dx.doi.org/10.1016/j.neuroimage.2004.07.051

[38] Woolrich MV, Jbabdi S, Patenaude B, Chappell M, Makni S., Behrens T., et al. Bayesian analysis of neuroimaging data in FSL. NeuroImage 2009; 45: S173-186. PMid: 19059349. http://dx.doi.org/10.1016/j.neuroimage.2008.10.055

[39] Cox RW. AFNI: software for analysis and visualization of functional magnetic resonance neuroimages. Comput Biomed Res. 1996; 29: 162-73. PMid: 8812068. http://dx.doi.org/10.1006/cbmr.1996.0014

[40] Cox RW, Hyde JS. Software tools for analysis and visualization of fMRI data. NMR Biomed. 1997; 10: 171-8. http://dx.doi.org/10.1002/(SICI)1099-1492(199706/08)10:4/5<171::AID-NBM453>3.0.CO;2-L

[41] Hoffman EJ, Huang SC, Phelps ME. Quantitation in positron emission computed tomography: 1. Effect of object size. J Comput Assist Tomogr. 1979; 3: 299-308. PMid: 438372. http://dx.doi.org/10.1097/00004728-197906000-00001

[42] Brooks RA, Di Chiro G. Principles of computer assisted tomography (CAT) in radiographic and radioisotopic imaging. Phys Med Biol. 1976; 21: 689-732. PMid: 788005. http://dx.doi.org/10.1088/0031-9155/21/5/001

[43] Townsend DW, Geissbuhler A, Defrise M, Hoffman EJ, Spinks TJ, Bailey DL, et al. Fully three-dimensional reconstruction for a PET camera with retractable septa. IEEE Trans Med Imaging. 1991; 10: 505-12. PMid: 18222855. http://dx.doi.org/10.1109/42.108584

[44] Phelps ME, Hoffman EJ, Huang SC, Ter-Pogossian MM. Effect of positron range on spatial resolution. J Nucl Med. 1975; 16: 649-52. PMid: 1151485

[45] Gautier JF, Chen K, Salbe AD, Bandy D, Pratley RE, Heiman M, et al. Differential brain responses to satiation in obese and lean men. Diabetes. 2000; 49: 838-46. PMid: 10905495. http://dx.doi.org/10.2337/diabetes.49.5.838

[46] Gautier JF, Del Parigi A, Chen K, Salbe AD, Bandy D, Pratley RE, et al. Effect of satiation on brain activity in obese and lean women. Obes Res. 2001; 9: 676-84. PMid: 11707534. http://dx.doi.org/10.1038/oby.2001.92

[47] Del Parigi A, Chen K, Gautier JF, Salbe AD, Pratley RE, Ravussin E, et al. Sex differences in the human brain's response to hunger and satiation.Am J Clin Nutr. 2002 Jun; 75(6): 1017-22. PMid: 12036808.

[48] Le DS, Pannacciulli N, Chen K, Del Parigi A, Salbe AD, Reiman EM, et al. Less activation of the left dorsolateral prefrontal cortex in response to a meal: a feature of obesity. Am J Clin Nutr. 2006; 84: 725-31. PMid: 17023697.

[49] DelParigi A, Chen K, Salbe AD, Hill JO, Wing RR, Reiman EM, Tataranni PA. Successful dieters have increased neural activity in cortical areas involved in the control of behavior. Int J Obes (Lond). 2007; 31: 440-8. PMid: 16819526.

http://dx.doi.org/10.1038/sj.ijo.0803431

[50] Raichle ME. Quantitative in vivo autoradiography with positron emission tomography. Brain Res. 1979; 180 : 47-68. http://dx.doi.org/10.1016/0165-0173(79)90016-X 
[51] Wang GJ, Volkow ND, Logan J, Pappas NR, Wong CT, Zhu W, et al. Brain dopamine and obesity. Lancet. 2001; 357: $354-357$. http://dx.doi.org/10.1016/S0140-6736(00)03643-6

[52] Haltia LT, Rinne JO, Merisaari H, Maguire RP, Savontaus E, Helin S, et al. Effects of intravenous glucose on dopaminergic function in the human brain in vivo. Synapse. 2007; 6: 748-756. PMid: 17568412. http://dx.doi.org/10.1002/syn.20418

[53] Volkow ND, Wang GJ, Telang F, Fowler JS, Thanos PK, Logan J, et al. Low dopamine striatal D2 receptors are associated with prefrontal metabolism in obese subjects: possible contributing factors. Neuroimage. 2008 Oct 1; 42(4): 1537-43. PMid: 18598772. http://dx.doi.org/10.1016/j.neuroimage.2008.06.002

[54] Lammertsma AA. Radioligand studies: imaging and quantitative analysis. Eur Neuropsychopharmacol. 2002; 12 : 513-6. http://dx.doi.org/10.1016/S0924-977X(02)00100-1

[55] Lammertsma AA, Bench CJ, Hume SP, Osman S, Gunn K, Brooks DJ, et al. Comparison of methods for analysis of clinical [11C]raclopride studies. Cereb Blood Flow Metab. 1996 Jan; 16(1): 42-52.

[56] Logan J, Fowler JS, Volkow ND, Wolf AP, Dewey SL, Schlyer DJ, et al. Graphical analysis of reversible radioligand binding from time-activity measurements applied to [N-11C-methyl]-(-)-cocaine PET studies in human subjects. J Cereb Blood Flow Metab. 1990; 10: 740-7. PMid: 2384545. http://dx.doi.org/10.1038/jcbfm.1990.127

[57] Logan J, Fowler JS, Volkow ND, Wang GJ, Ding YS, Alexoff DL. Distribution volume ratios without blood sampling from graphical analysis of PET data. J Cereb Blood Flow Metab. 1996; 16: 834-40. PMid: 8784228. http://dx.doi.org/10.1097/00004647-199609000-00008

[58] Zubieta JK, Ketter TA, Bueller JA, Xu Y, Kilbourn MR, Young EA, et al. Regulation of human affective responses by anterior cingulate and limbic mu-opioid neurotransmission. Arch Gen Psychiatry. 2003; 60: 1145-53. PMid: 14609890. http://dx.doi.org/10.1001/archpsyc.60.11.1145

[59] Rota D, Lafortuna CL, Rizzo G, Sartorio A, Agosti F, Panzacchi A, et al. Modifications of mu-opioid receptors in obesity. Neuroimage. 2008; 41 (Suppl 2): T193. http://dx.doi.org/10.1016/j.neuroimage.2008.04.160

[60] Hill DL, Batchelor PG, Holden M, Hawkes DJ. Medical image registration. Phys Med Biol. 2001; 46: R1-45. PMid: 11277237. http://dx.doi.org/10.1088/0031-9155/46/3/201

[61] Talairach J, Tournoux P. Co-planar stereotactic atlas of the human brain. New York: Thieme Medical Publisher. 1988. PMid: 3129671.

[62] Crum WR, Hartkens T, Hill DL. Non-rigid image registration: theory and practice. Br J Radiol. 2004; 77 Spec No 2: S140-53. PMid: 15677356. http://dx.doi.org/10.1259/bjr/25329214

[63] Gibson CD, Carnell S, Ochner CN, Geliebter A. Neuroimaging, gut peptides and obesity: novel studies of the neurobiology of appetite. J Neuroendocrinol. 2010; 22: 833-45. PMid: 20553371.

[64] De Graaf C, Blom WA, Smeets PA, Stafleu A, Hendriks HF. Biomarkers of satiation and satiety. Am J Clin Nutr. 2004; 79: 946-61. PMid: 15159223.

[65] Tataranni PA, Gautier JF, Chen K, Uecker A, Bandy D, Salbe AD, et al. Neuroanatomical correlates of hunger and satiation in humans using positron emission tomography. Proc Natl Acad Sci U S A. 1999; 96: 4569-4574. PMid: 10200303. http://dx.doi.org/10.1073/pnas.96.8.4569

[66] Schwartz MW, Woods SC, Porte D Jr, Seeley RJ, Baskin DG. Central nervous system control of food intake. Nature. 2000; 404: 661-671. PMid: 10766253.

[67] Yu JH, Kim MS. Molecular mechanisms of appetite regulation. Diabetes Metab J. 2012; 36: 391-398. PMid: 23275931. http://dx.doi.org/10.4093/dmj.2012.36.6.391

[68] Carnell S, Gibson C, Benson L, Ochner CN, Geliebter A. Neuroimaging and obesity: current knowledge and future directions. Obes Rev. 2012; 13: 43-56. PMid: 21902800. http://dx.doi.org/10.1111/j.1467-789X.2011.00927.x

[69] Smeets PA, Charbonnier L, Van Meer F, Van der Laan LN, Spetter MS. Food-induced brain responses and eating behaviour. Proc Nutr Soc. 2012; 71: 511-520. PMid: 22931854. http://dx.doi.org/10.1017/S0029665112000808

[70] Hollmann M, Pleger B, Villringer A, Horstmann A. Brain imaging in the context of food perception and eating. Curr Opin Lipidol. 2013; 24: 18-24. PMid: 23165087. http://dx.doi.org/10.1097/MOL.0b013e32835b61a4

[71] Kroemer NB, Krebs L, Kobiella A, Grimm O, Pilhatsch M, Bidlingmaier M, et al. Fasting levels of ghrelin covary with the brain response to food pictures. Addict Biol. 2013; 18: 855-862. PMid: 22974271. http://dx.doi.org/10.1111/j.1369-1600.2012.00489.x

[72] Wang GJ, Tomasi D, Backus W, Wang R, Telang F, Geliebter A, et al. Gastric distention activates satiety circuitry in the human brain. Neuroimage. 2008; 39: 1824-1831. PMid: 18155924. http://dx.doi.org/10.1016/j.neuroimage.2007.11.008

[73] Pannacciulli N, Le DS, Salbe AD, Chen K, Reiman EM, Tataranni PA, et al. Postprandial glucagon-like peptide-1 (GLP-1) response is positively associated with changes in neuronal activity of brain areas implicated in satiety and food intake regulation in humans. Neuroimage. 2007; 35: 511-517. PMid: 17317222. http://dx.doi.org/10.1016/j.neuroimage.2006.12.035 
[74] Berridge KC. 'Liking' and 'wanting' food rewards: brain substrates and roles in eating disorders. Physiol Behav. 2009 ; 97: 537-550. PMid: 19336238. http://dx.doi.org/10.1016/j.physbeh.2009.02.044

[75] Kringelbach ML, De Araujo IE, Rolls ET. Taste-related activity in the human dorsolateral prefrontal cortex. Neuroimage. 2004; 21: 781-788. PMid: 14980581. http://dx.doi.org/10.1016/j.neuroimage.2003.09.063

[76] Gottfried JA, O'Doherty J, Dolan RJ. Encoding predictive reward value in human amygdala and orbitofrontal cortex. Science. 2003; 301: 1104-1107. PMid: 12934011. http://dx.doi.org/10.1126/science.1087919

[77] Rothemund Y, Preuschhof C, Bohner G, Bauknecht HC, Klingebiel R, Flor H, et al. Differential activation of the dorsal striatum by high-calorie visual food stimuli in obese individuals. Neuroimage. 2007; 37: 410-421. PMid: 17566768. http://dx.doi.org/10.1016/j.neuroimage.2007.05.008

[78] Martin LE, Holsen LM, Chambers RJ, Bruce AS, Brooks WM, Zarcone JR, et al. Neural mechanisms associated with food motivation in obese and healthy weight adults. Obesity (Silver Spring). 2010; 18: 254-260. PMid: 19629052. http://dx.doi.org/10.1038/oby.2009.220

[79] Bragulat V, Dzemidzic M, Bruno C, Cox CA, Talavage T, Considine RV, et al. Food-related odor probes of brain reward circuits during hunger: a pilot FMRI study. Obesity (Silver Spring). 2010; 18: 1566-1571. PMid: 20339365. http://dx.doi.org/10.1038/oby.2010.57

[80] DelParigi A, Chen K, Salbe AD, Reiman EM, Tataranni PA. Sensory experience of food and obesity: a positron emission tomography study of the brain regions affected by tasting a liquid meal after a prolonged fast. Neuroimage. 2005; 24 : $436-443$. PMid: 15627585. http://dx.doi.org/10.1016/j.neuroimage.2004.08.035

[81] Berridge KC, Robinson TE. What is the role of dopamine in reward: hedonic impact, reward learning, or incentive salience? Brain Res Brain Res Rev. 1998; 28: 309-369. http://dx.doi.org/10.1016/S0165-0173(98)00019-8

[82] O'Doherty JP, Deichmann R, Critchley HD, Dolan RJ. Neural responses during anticipation of a primary taste reward. Neuron. 2002; 33: 815-826. http://dx.doi.org/10.1016/S0896-6273(02)00603-7

[83] Berns GS, McClure SM, Pagnoni G, Montague PR. Predictability modulates human brain response to reward. J Neurosci. 2001; 21: 2793-2798. PMid: 11306631.

[84] LaBar KS, Gitelman DR, Parrish TB, Kim YH, Nobre AC, Mesulam MM. Hunger selectively modulates corticolimbic activation to food stimuli in humans. Behav Neurosci. 2001; 115: 493-500. PMid: 11345973. http://dx.doi.org/10.1037/0735-7044.115.2.493

[85] Kelley AE, Bakshi VP, Haber SN, Steininger TL, Will MJ, Zhang M. Opioid modulation of taste hedonics within the ventral striatum. Physiol Behav. 2002; 76: 365-377. http://dx.doi.org/10.1016/S0031-9384(02)00751-5

[86] Davis CA, Levitan RD, Reid C, Carter JC, Kaplan AS, Patte KA, et al. Dopamine for "wanting" and opioids for "liking": a comparison of obese adults with and without binge eating. Obesity (Silver Spring). 2009 Jun; 17(6): 1220-5

[87] Small DM, Gregory MD, Mak YE, Gitelman D, Mesulam MM, Parrish T. Dissociation of neural representation of intensity and affective valuation in human gustation. Neuron. 2003; 39: 701-711. http://dx.doi.org/10.1016/S0896-6273(03)00467-7

[88] De Araujo IE, Kringelbach ML, Rolls ET, McGlone F. Human cortical responses to water in the mouth, and the effects of thirst. J Neurophysiol. 2003; 90: 1865-1876. PMid: 12773496. http://dx.doi.org/10.1152/jn.00297.2003

[89] Kringelbach ML, O'Doherty J, Rolls ET, Andrews C. Activation of the human orbitofrontal cortex to a liquid food stimulus is correlated with its subjective pleasantness. Cereb Cortex. 2003; 13: 1064-1071. PMid: 12967923. http://dx.doi.org/10.1093/cercor/13.10.1064

[90] Small DM, Zatorre RJ, Dagher A, Evans AC, Jones-Gotman M. Changes in brain activity related to eating chocolate: from pleasure to aversion. Brain. 2001; 124: 1720-1733. PMid: 11522575. http://dx.doi.org/10.1093/brain/124.9.1720

[91] Hollmann M, Hellrung L, Pleger B, Schlögl H, Kabisch S, Stumvoll M, et al. Neural correlates of the volitional regulation of the desire for food. Int J Obes (Lond). 2012; 36: 648-655. PMid: 21712804. http://dx.doi.org/10.1038/ijo.2011.125 